ACTA MYCOLOGICA

Vol. 45 (2): 129-131

2010
Dedicated to Professor Barbara Gumińska on the occasion of her eighty-fifth birthday

\title{
Laricifomes officinalis in the Gorce Mountains (S Poland)
}

\author{
WŁADYSŁAW WOJEWODA \\ Department of Mycology, W. Szafer Institute of Botany, Polish Academy of Sciences \\ Lubicz 46, PL-31-512 Kraków
}

Wojewoda W.: Laricifomes officinalis in the Gorce Mountains (S Poland). Acta Mycol. 45 (2): 129-131, 2010.

Information about second finding of Laricifomes officinalis (Batsch) Kotl. \& Pouzar (Fomitopsidaceae) in the Gorce Mountains in the External Western Carpathians is given, and its legitimate and illegitimate selected synonyms are cited. This species in Poland is very rare and threatened.

Key words: Polyporales, distribution, Western Carpathians, fungal conservation

\section{INTRODUCTION}

Laricifomes officinalis is very rare in Poland (Wojewoda, Ławrynowicz 2006). Historical localities of L. officinalis are cited by Łuszczyński (2000) and Chlebicki \& Łuszczyński (2002). The six contemporary localities were mentioned by Piętka and Szczepkowski (2004). In last years this species was published as Fomitopsis officinalis (Vill.) Bondartsev \& Singer (e.g., Ryvarden, Gilbertson 1993; Wojewoda 2003).

\section{TAXONOMY}

Laricifomes officinalis (Batsch) Kotl. \& Pouzar

Basionym: Boletus officinalis Batsch, Elenchus fungorum: 111. 1783 (legitimate). Current name: Laricifomes officinalis (Batsch) Kotl. \& Pouzar, Česká Mykol. 11(3): 158. 1957, legitimate.

Synonyms: Boletus officinalis Vill., Histoire des plantes du Dauphine 3: 1041. 1789, illegitimate; Fomes officinalis (Batsch) Bres., Iconographia mycologica 20: 
989. 1931, legitimate; Fomitopsis officinalis (Batsch) Bondartsev \& Singer, Ann. Mycol. 39: 55. 1941, legitimate; Agaricum officinale (Batsch) Donk, Proceeding van de Koninklijke Nederlandse Aka Wetenschappen Section C 74 (1): 26. 1974, illegitimate (MycoBank 2009).

Classification according to Kirk et al. (2008): Fungi, Basidiomycota R.T. Moore (1980), Agaricomycotina Doweld (2001), Agaricomycetes Doweld (2001), Agaricomycetidae Parmasto (1986), Polyporales Gäum. (1926), Fomitopsidaceae Jülich (1982), Laricifomes Kotl. \& Pouzar (1957).

\section{DISTRIBUTION IN THE GORCE MOUNTAINS}

In the Polish Carpathians hitherto is known only one locality of Laricifomes officinalis in Krościenko nad Dunajcem (Skirgiełło 1959; Wojewoda 1991). In the Herbarium of the Institute of Botany, University of Warsaw is preserved the one fragment of basidioma of Fomes officinalis (Vill.) Neuman: Krościenko, 1955, Sept. 28, coll. A. Skirgiełlo, det. H. Orłoś, WA 7195. During the excursion in September 1955 in the vicinity of Krościenko nad Dunajcem (Skirgiełło 1959, 2006) the fungi were collected in three geographical regions: the Beskid Sacdecki Mts, the Gorce Mts and the Pieniny Mts, but exact localities are not mentioned. According to Skirgiełło (l.c.) most aphyllophoroid fungi were collected on the slope of 'the elevation over Zakrętki' (it is the mount Marszałek in the Gorce Mountains, Wojewoda 1991).

In 1970 Laricifomes officinalis was found probably in the same locality: S Poland, the External Western Carpathians, the Gorce Mountains, on S slope of the mount Marszałek, under the peak of this mountain, ca $750 \mathrm{~m}$ a.s.l., in the larch forest with Abies alba, Fagus sylvatica and Picea abies, ca $3 \mathrm{~km}$ N of Krościenko nad Dunajcem centre, on the trunk of old living Larix decidua, 1970, April 17, coll. W. Wojewoda, KRAM-F 48001 (Fig. 1). It is necessary to search this species on the mount Marszałek.

Acknowledgments. I should like to thank Dr. Maja Graniszewska, the curator of the Herbarium of the Institute of Botany, University of Warsaw for loan the specimen of $L$. officinalis from Krościenko nad Dunajcem.

\section{REFERENCES}

Chlebicki A., Luszczyński J. 2002. Fomitopsis officinalis (Vill.: Fr.) Bondartsev \& Singer. Atlas of the geographical distribution of fungi in Poland 2: 61-67.

Kirk P. M., Cannon P. F., Minter D. W., Stalpers J. A. 2008. Ainsworth \& Bisby's Dictionary of Fungi. 10. ed. CABI Europe - UK. Trowbridge, 771 pp.

Łuszczyński J. 2000. Fomitopsis officinalis (Coriolaceae) w Polsce. Fragm. Flor. Geobot. Polonica 7: 271276.

MycoBank 2009. http://www.mycobank.org.

Piętka J., Szczepkowski A. 2004. Localities of Fomitopsis officinalis in Poland. Acta Mycol. 39 (1): 33-45. Ryvarden L., Gilbertson R. L. 1993. European Polypores. 1. Syn. Fung. 6. Fungiflora, Oslo, 387 pp.

Skirgiełlo A. 1959. Notatki mikologiczne z okolic Krościenka nad Dunajcem. Monogr. Bot. 8: 229-235.

Skirgiełlo A. 2006. Zapiski ze stuletniego życia. BEL Studio Sp., Warszawa, 151 pp. 


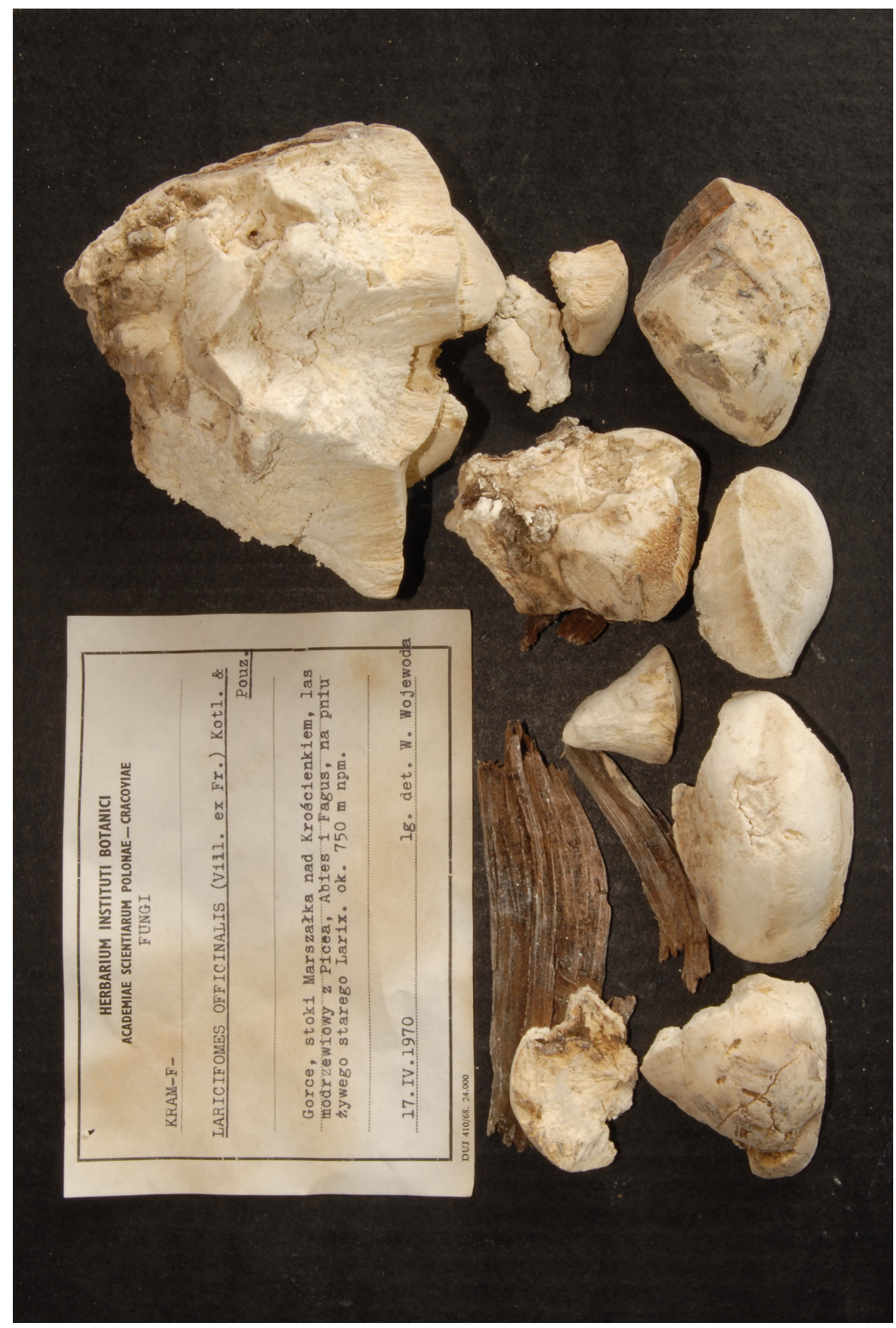

Fig. 1. Laricifomes officinalis preserved in the Herbarium KRAM F of the W. Szafer Institute of Botany, Polish Academy of Sciences in Kraków. 
Wojewoda W. 1991 (1990). Pierwsza czerwona lista grzybów wielkoowocnikowych (macromycetes) zagrożonych w Polskich Karpatach. Studia Ośr. Dokum. Fizjogr. PAN Oddz. Kraków 18: 239-261.

Wojewoda W. 2003. Checklist of Polish larger Basidiomycetes. (In:) Z. Mirek (ed.). Biodiversity of Poland 7: 1-812. W. Szafer Institute of Botany, Polish Academy of Sciences, Kraków.

Wojewoda W., Ławrynowicz M. 2006. Red list of the macrofungi in Poland. (In:) Z. Mirek, K. Zarzycki, W. Wojewoda, Z. Szeląg (eds). Red list of plants and fungi in Poland. 3. ed.: 53-70. W. Szafer Institute of Botany, Polish Academy of Sciences, Kraków.

\section{Laricifomes officinalis w Gorcach (Pd. Polska)}

\section{Streszczenie}

We wrześniu 1955 roku A. Skirgiełło zorganizowała wycieczkę mikologiczną w Karpaty, do Krościenka nad Dunajcem. Uczestnicy: A. Skirgiełło, B. Gumińska, A. Nespiak i M. Lisiewska (Skirgiełło 1959, 2006) zbierali grzyby w trzech regionach fizyczno-geograficznych: w Beskidzie Sądeckim, Gorcach i Pieninach. Dla okazu L. officinalis znajdującego się w Zielniku Zakładu Systematyki i Geografii Roślin Instytutu Botaniki Uniwersytetu Warszawskiego jako stanowisko podane jest „Krościenko” ale Skirgiełlo (1959) informuje, że przeważającą liczbę Polyporaceae zebrano na zboczu „wzniesienia nad Zakrętkami”. Wymienione „wzniesienie” to góra Marszałek w Gorcach, leżąca ponad Krościenkiem nad Dunajcem. Uczestnicy wycieczki zbierali grzyby także na szczycie tej góry. W 1970 r. autor zebrał L. officinalis pod szczytem Marszałka, być może na tym samym stanowisku, na którym gatunek ten znalazła A. Skirgiełlo w 1955 r. W. Wojewoda zebrał okazy tego gatunku 40 lat temu. Nie wiadomo czy stanowisko to się zachowało. Konieczne jest poszukiwanie na Marszałku tego bardzo rzadkiego i zagrożonego w Polsce grzyba.

Gatunek ten w ostatnich latach wymieniany był w publikacjach pod nazwą Fomitopsis officinalis (Vill.) Bondartsev \& Sing. Obecnie obowiązuje uprawniona nazwa Laricifomes officinalis (Batsch) Kotl. \& Pouzar (MycoBank 2009). 